\title{
How New Solo Entrepreneurs Can Think Through Their Finances
}

\author{
Roy Carriker (Drexel University)
}

KEYWORDS: Entrepreneurship, Teaching Methods, Family Business.

Today people can no longer count on a steady paycheck in a predictable amount from an employer. We're seeing ever-growing numbers of "unintended entrepreneurs" -- once-employed people forced to become the entrepreneurs of their own lives because of job losses and/or increasingly limited opportunities to earn a satisfactory living. A recent study by McKinsey (https://www.mckinsey.com/featured-insights/employme nt-and-growth/independent-work-choice-necessity-andthe-gig-economy) suggests roughly $40 \%$ of the US workforce are either full-time independent workers or work part-time to augment income, and that this figure is growing. Most of these unintended entrepreneurs know nothing about starting a business and are unprepared for the financial challenges involved. Colleges, universities and even high schools (https://familybusiness.org/content/291-entrepreneurshi p-education-must-start-before-college?search=entrepre neurship\%20starts\%20before\%20college) must focus more on preparing students in all disciplines to be unintended entrepreneurs. In the meantime, one easy-touse tool -- the Marginal Income Model (MIM) -- can help them think through the financial challenges.

MIM helps people with no financial training, but facing self-employment, frame the basic financial issues they should consider. It can provide a structured way of thinking through very basic financial decisions about becoming an independent contractor or company-ofone. While intended for self-employed people, these concepts can also be useful to a more sophisticated startup with multiple employees.

\section{The Three Legged Stool of Entrepreneurship}

The basic foundation of a startup is like the legs of a three-legged stool, each serving to create stability:

- Is it real?

\section{- It takes a team \\ - Cash is king}

"Is it real?" refers to the product or service under consideration. Historically startups have had a very high failure rate because they couldn't be sure enough customers really wanted the product or service and would pay the envisioned price. Today new entrepreneurs have ways to ensure a greater chance of success because of what is called a Minimum Viable Product (MVP). Very simply put, this means finding a way to quickly test-market the product/service idea to determine if a real market exists and the viable pricing model. Establishing an MVP is an exercise in itself and will not be covered here.

"It takes a team" refers to a long list of issues someone starting an enterprise should consider -- which business form the startup should take (proprietorship, limited liability corporation, etc.); whether liability insurance is needed and if so, how much; how to market; tax considerations; etc.-- and which expertise should be sought from mentors and professionals to avoid pitfalls.

Finally, "cash is king" refers to the financial challenges of running the business. Simple startups typically are funded from a checkbook, usually with limited cash resources, and if the cash runs out the startup may be dead unless it can line up enough cash from other sources. The financial accounting for a self-employment startup isn't very complex, but requires a great deal of discipline. The Marginal Income Model discussed here is invaluable in examining the startup financial dynamics such as pricing, how much cash may be needed, how long the cash on hand may last, and other issues.

\section{Getting Started}

Once the viability of the proposed product or service (dog walker, handy man, portrait artist, etc.) has been established, the entrepreneur must figure out its price.

Copyright (C) 2018 The Authors. Entrepreneur \& Innovation Exchange is published at EIX.org. This is an open access article under the terms of the Creative Commons Attribution-NoDerivs License, which permits use and distribution in any medium, provided the original work is properly cited and 
Checking competitive offerings can be a very useful guide. If the idea seems unique, assessing viability often means surveying a sample variety of potential customers with a product prototype or at least description. Feedback from this may lead to altering the offering or its pricing (pivoting) and may even lead to the realization that the business idea isn't viable. Once the idea has been shown to have realizable potential, i.e., is "real," and there is at least a price range to consider, one can proceed to the "cash is king" stage of the exercise using the MIM, which can also help in finetuning pricing.

\section{Marginal Income Model - Cash Needs}

To begin modeling an independent worker startup using the MIM, compartmentalize the finances for the start-up into categories. First is Up-front Investment, the funds spent to set up the business well before the first sale or transaction. Because running out of cash is a major problem for startups, the focus here should be how to keep up-front investment to a minimum and still successfully pursue the business. Examples of up-front investments could be business cards, a dedicated cell phone, computer, kitchenware for a baking business, etc.

The second compartment is Fixed Expense. These are the continuing expenses which go on independently of the level of sales. For an independent worker, first and foremost are personal expenses such as food, rent, car, phone, internet service, etc. So the first step is to create a budget plan for these living expenses. This budget should include identifying discretionary expenses that can be eliminated. Examples of other fixed expenses in starting up might include manufacturing space rent, equipment leases, advertising, etc.

The third compartment for examining the use of funds is Variable Costs. These are the costs that vary directly with the level of sales activity. Examples would include the materials that go into the product, packaging, shipping, the cost of sales visits to potential customers, etc.

A fourth compartment is Marginal Income, which is the price charged minus the variable cost for each transaction. To build the model of the business, first look at marginal income on a per unit of sale basis. That is, in selling an item or a service, what is the price of a single unit of sale less the variable cost involved in making that sale? This gives a way to look at how many single transactions and the marginal income produced from them each month will cover the entrepreneur's fixed expenses for that month. When this happens, the startup has achieved a Breakeven Run Rate -- i.e., has stopped losing money. Other time spans may be used, but generally businesses are looked at on a monthly basis.

As a startup commences business it usually takes some period of time to attain a breakeven run rate. Adding up the monthly losses until this is achieved gives the startup's Cumulative Operating Loss. After a startup attains a breakeven run rate and begins to accumulate marginal income each month, the startup is said to have attained Breakeven when the accumulation of marginal income equals its cumulative operating losses.

Some prefer to think of Breakeven as being when the accumulation of marginal income equals the sum of all operating losses plus the upfront investment. In either way of thinking, it is an extremely important milestone for a startup.

In brief, to use MIM to model a startup:

- Determine up-front investment

- Determine fixed expenses

- Determine variable costs

- Set pricing per transaction

- Calculate Marginal Income per transaction

- Project a roadmap of sales growth

- Calculate accumulated operating losses until a breakeven run rate is achieved

- Add up-front investment to accumulated losses to establish startup cash required

- Vary estimates made in modeling to test sensitivity to modeling assumptions

It should be noted a critical element of the model is determining how many transactions will it take to reach a breakeven run rate -- i.e., how many transactions does it take for the marginal income to add up to the fixed expenses in the accounting period being used.

\section{Example: Solo Consultant}

Let's use as an example a person wanting to become a self-employed consultant. First, try to estimate funds needed to start the business even before the first transaction. Costs incurred before even making a first 
business call might include setting up a website, having business cards and stationery printed, and investing in a more powerful computer and a dedicated phone line with an answering machine for the business. For the purposes of this exercise let's say this bucket of funds, the up-front investment, is $\$ 2,400$.

Once the up-front investment has been made and the business started, typically it won't make enough money to cover the entrepreneur's up-front investment and living expenses right away. This is a period of negative cash flow -- i.e., more cash is going out than is coming in. Let's dissect what's going on here using theMarginal Income Model.

Let's assume the consultancy business is conducted from home and is the only source of income. The business will have two types of costs, variable costs and fixed costs. In this example what costs would be fixed costs? Since the consulting startup is the only source of income, the residence costs (mortgage, rent, utilities etc.) plus personal living expenses (food, etc.) all represent fixed costs. These costs go on regardless of your level of business activity or success. A budget for these fixed costs needs to be developed and an effort made to minimize them while getting started -- for example by cutting out all discretionary spending. For this exercise, let's say the fixed costs are $\$ 3000$ a month.

How do we define variable costs? For this consultancy example these are the costs that vary directly with the business activity level. For example, costs of traveling to make a client presentation, to follow-up or to deliver a report would be a variable costs even though no sale was made because they vary directly with the business activity. Other costs falling into this category would be entertainment expenses, lunches and other costs incurred while dealing with a potential client. Thus even a consultancy can incur considerable variable costs without making a sale. For a product business, variable costs tend to be a bit more straightforward and more directly tied to the product: manufacturing, packaging and shipping costs.

To first understand how the math of the MIM works, let's consider the figures in the MIM below to be the actual results of the consulting startup. In this hypothetical consultancy model, let's assume that a lot of prospecting, but no sale, happens in the first month of the business. Further, let's say $\$ 400$ of variable costs were spent in pursuit of business. Thus in the first month the consultancy had a negative cash flow of $\$ 3,400$ ( $\$ 3,000$ fixed expenses and $\$ 400$ variable costs). Below is a chart of the hypothetical financial performance of the start-up month by month for the first nine months. For this exercise we'll assume the pricing was viable.

\section{Example: Consultancy MIM}

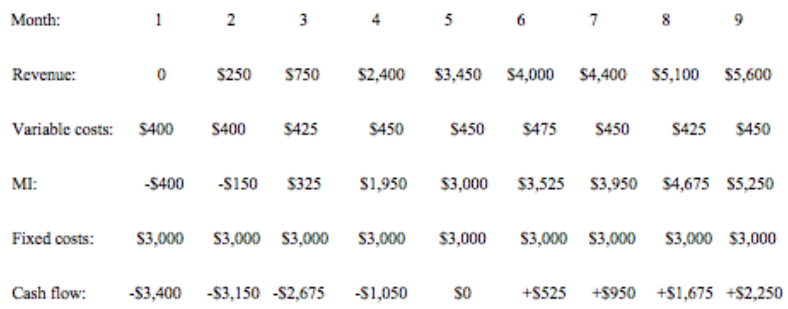

Now how should we look at these cash flows in our example start-up consultancy? First let's concentrate on the marginal income (MI), which is defined as the revenue minus the variable costs. Thus we see in the first month our marginal income is a negative $\$ 400$, i.e., $\$ 400$ was spent on prospecting but there were no sales. In the second month there were some sales, reducing the marginal income to a negative $\$ 150$. By the third month we have a positive marginal income of $\$ 325$, and so the calculation of marginal income goes for each month.

The next thing we want to look at in the example is how much cash was needed to cover cumulative losses until marginal income began covering fixed costs, which in the example was month five. In months one through five there was an accumulated negative cash flow of $-\$(3,400+3,150+2,675+1,050+0)$, for a total startup operating loss of $\$ 10,275$ until reaching a profitable run rate. Added to the upfront investment of $\$ 2,400$, this means a minimum startup capital of $\$ 10,275+\$ 2,400=$ $\$ 12,675$ needed to be planned.

Why look at this marginal income figure month by month? We look at the business in this way because of the fixed costs of $\$ 3000$ a month, which the marginal income must more than cover to begin to have a profitable business. As we see in this hypothetical example, by month five a breakeven run rate has been reached -- that is, the $\$ 3450$ in revenue covers both the variable and fixed costs. After month 5 marginal income is now exceeding fixed costs and the consultancy is 
beginning to turn a profit.

Let's say for the moment the figures shown in the table were not the results of the startup business, but the business plan, or perhaps more properly "Roadmap" of how the business was expected to go. The term Roadmap is used because startups have so much uncertainty in how things will go, particularly around revenues and their timing, that the term "business plan" seems a bit fixed. Many bumps and detours are likely when following a startup roadmap.

The example roadmap shows a need for $\$ 12,675$ to reach a point where the business could sustain itself. Generally speaking, a startup roadmap or budget must include contingency funds set aside -- because even with meticulous planning unforeseen events will still either add to the costs experienced or the time required to reach a breakeven run rate. So, in the example discussed, it would be prudent to have significantly more than $\$ 12,675$ set aside as startup capital.

In this example the business has reached profitability and is accumulating profits. While taxes and accounting nuances alter this picture in terms of precision, the business fundamentals hold true and help provide a conceptual framework for assessing the financial viability of a business opportunity. Taxes are not considered here because the focus is on how to roadmap the business for reaching profitability, and taxes won't kick in until profitability is attained. Of course the overarching principle in any business startup assessment is: Is there a real unfulfilled market need or at least one under-served by the competition?

\section{A Versatile Tool}

This model can be applied to much more complex business opportunities than being a self-employed consultant. Its definitions and principles can apply for any business. For example, in starting a restaurant, the model would show startup capital to be quite large relatively speaking, marginal income per transaction to be low and fixed costs to be relatively high, all implying that the minimum startup capital is still relatively large and very careful budgeting is necessary. It might also lead to the conclusion that outside investors are needed for the startup capital. Because of the risks for the capital they would invest, it implies they would want to have a significant share of the return; in other words, a significant ownership stake. Further, most likely investors would be looking for a business that can be scaled up if it's successful. For example, they are not just investing in a single restaurant, but also in the potential for a chain of restaurants using the same model or franchising.

Besides looking at the cost side of a startup and the capital that may be required, this simple model can also help with pricing decisions. When the price of a new product or service isn't abundantly clear, playing with the pricing in the business model can help point the way to a strategy (For example, at a given price, how many transactions will be necessary to generate a marginal income that can cover the fixed expenses?) In other words, it allows one to look at the trade-off between pricing for a relatively high marginal income for lower volume versus pricing at a lower marginal income but planning for much higher sales volumes.

The model also helps make the important distinction between variable and fixed costs, and ultimately, how many marginal income events (the price of a transaction less the variable costs of the transaction) in an accounting period are needed to cover the fixed costs in that period. In the case of a restaurant, clearly the food is a variable cost, varying directly with transaction. A cost item like staff is slightly more complicated. Some of the staff may be considered variable cost because they only work part-time as volume dictates, but the cook has to be considered a fixed expense since he/she has to be available to prepare the food whether or not there are any customers.

In using the Marginal Income Model for a manufactured product, is hiring someone to assemble the product or help deliver it a variable cost because there is labor involved in each item sold, or is it a fixed expense? Generally in a start-up the labor has to be hired regardless of volume and thus has to initially be looked at as a fixed expense. If the labor could be arranged on an as-needed or piece-work contract (i.e., only pay for labor on an item by item basis), then the labor would be considered a variable cost. The MIM allows one to examine the trade-offs in these kinds of issues to project what strategy has the highest probability of conserving cash until the startup has achieved financial stability.

\section{Conclusion}

Of course in the end, using a MIM Roadmap to financially model a business is more complex than has been presented here. For example in this model we didn't consider business taxes and issues such as 
capital equipment depreciation, potential loan interest, time value of money, etc. However, this simple model does provide a way to think about the principal financial issues of a startup, which include but aren't limited to:

- The upfront investment, which in most instances should be considered entirely at risk if things don't go as planned

- Startup operating losses

- Minimum capital requirements, including allowing for some financial reserve

- Classifying costs into two categories, variable and fixed

- Identifying the marginal income expected in the business and how many transactions will be required to cover the fixed costs

- Time required to attain a breakeven run rate

- Time to breakeven on the capital invested in the business

- Pricing the product or service

- Investing to lower costs and improve marginal income vs. accepting lower marginal income through contract manufacturing, etc., but preserving more funds in reserve for more staying power

Additional Search Terms: entrepreneurship courses, teaching ideas, teaching resources, classroom ideas, entrepreneurship classes, business schools, business school classes, entrepreneurship students, professors 